UDC 336.132:338.43

DOI: https://doi.org/10.32851/2708-0366/2021.10.17

Tanklevska Nataliya

D.Sc. in Economics, Professor

Kherson State Agrarian and Economic University

ORCID: https://orcid.org/0000-0003-2906-4051

\title{
THE IMPACT OF FINANCIAL INSTRUMENTS ON BUSINESS DEVELOPMENT
}

The article identifies theoretical approaches to the formation of a set of financial instruments that directly affect the development of enterprises. Objective and subjective factors that affect the dynamics and efficiency of financial instruments are identified. The expediency of using financial forecasting as one of the financial methods, which allows to predict the development of economic processes in the future, as well as financial planning. If financial forecasting is a strategy for developing state finances in a certain perspective, then financial planning is tactical ways to achieve this perspective. Emphasis is placed on the need to apply the budgeting system in financial planning, especially in the context of market relations and financial turbulence. It is determined that financial control is a necessary condition for uninterrupted, efficient and gradual business development. The classification of types, forms and methods of financial control is given. Peculiarities of financial regulation of activity of business entities are determined, the basic principles of the liberal concept and the concept of state regulation are considered. The main instrument of socio-economic development as a managed process in a market economy is the economic and legal mechanism of state regulation, which includes both the system of privileges and subsidiary financial means of development, as well as a set of regulations and measures aimed at limiting certain unsatisfactory consequences of economic activity. Moreover, the financial levers of influence on the development of business structures are given. Only the complex application of all financial instruments can ensure the qualitative development of business entities. Among all financial levers, a special place is occupied by taxes and fees, through which the state mobilizes funds to perform its functions, as well as affects and encourages entrepreneurial activity, promotes investment activity etc. In a market economy, the use of administrative methods of influence is too limited, and therefore the main emphasis in the regulation of the economy is on taxation and financial stimulation of business structures development. Issues of ensuring the financial stability of business entities, strengthening their financial security, as well as identifying factors that affect the state and development of enterprise financing may be topics for further research.

Key words: finance, business, financial instruments, financial forecasting, financial planning, financial control, financial levers, business entities.

В статті визначені теоретичні підходи до формування сукупності фінансових інструментів, які безпосередньо впливають на розвиток підприємств. Визначено об'єктивні та суб'єктивні фактори, які впливають на динаміку та ефективність фінансових інструментів. Обгрунтовано дочільність застосування фінансового прогнозування як одиного з фінансових методів, який дозволяє передбачати розвиток економічних процесів на перспективу, а також фінансового планування. Здійснено акиент на необхідності при фінансовому плануванні застосовувати систему бюджетування, особливо в умовах розвитку ринкових відносин та фінансової турбулентності. Визначено, що фінансовий контроль $\epsilon$ необхідною умовою безперебійного, ефективного й поступового розвитку бізнесу. Наведено класифікаиію видів, форм та методів фінансового контролю. Визначено особливості фінансового регулювання діяльності суб 'єктів господарювання, розглянуто основні принципи ліберальної конщепиії $і$ конщепції державного регулювання. Наведено фінансові важелі впливу на розвиток бізнес-структур.

Ключові слова: фінанси, бізнес, фінансові інструменти, фінансове прогнозування, фінансове планування, фінансовий контроль, фінансові важелі, суб 'єкти господарювання.

В статье определены теоретические подходы к формированию совокупности финансовых инструментов, непосредственно влияющих на развитие предприятий. Определены объективные и субъективные факторы, влияющие на динамику и эффективность финансовых инструментов. Обоснована целесообразность применения финансового прогнози- 
рования как одного из финансовых методов, позволяющего предусматривать развитие экономических проиессов на перспективу, а также финансового планирования. Акиент на необходимости при финансовом планировании применять систему бюджетирования, особенно в условиях развития рыночных отношений и финансовой турбулентности. Установлено, что финансовый контроль является необходимым условием бесперебойного, эффективного и постепенного развития бизнеса. Приведена классификация видов, форм и методов финансового контроля. Определены особенности финансового регулирования деятельности хозяйствующих субъектов, рассмотрены основные принципь либеральной концепции и концепции государственного регулирования. Приведены финансовые рычаги влияния на развитие бизнес-структур.

Ключевые слова: финансы, бизнес, финансовые инструменты, финансовое прогнозирование, финансовое планирование, финансовый контроль, финансовыле рычаги, предприятия.

Problem statement. The impact on the development of the national economy and its individual entities is carried out through financial instruments based on the relevant structural elements of the financial mechanism. The combination of the elements of the financial mechanism is its "design", which is activated by setting the quantitative parameters of each element, that is, the definition of rates and rates of withdrawal of funds, the volume of funds, the level of expenditures, etc. The purpose of the financial mechanism ultimately comes down to the financial support and financial regulation of economic and social processes in the state.

Review of recent researches and publications. The theoretical foundations of the financial categories "finance" and "financial instruments" are defined in the works of Aristotle, L. Abalkin, A. Bukovetsky, S. Witte, I. Kaufman, J. Keynes, R. Coase, A. Marshall, A. Montchretien, I. Ozerova, W. Petty, D. Ricardo, A. Smith, M. Speransky, I. Yanzhula. A significant contribution to the study of theoretical and practical principles of finance, financial policy and its individual components was made by prominent foreign and domestic scientists: M. Alexandrova, O. Vasylyk, Z. Vasylchenko, V. Hrushko, L. Khudoliy, M. Krupka, V. Kudryashov, V. Lagutin, I. Lutyi, V. Martynenko, V. Oparin, I. Petrovska, A. Podderogin, V. Rodionova, O. Romanenko, B. Sabanti, V. Savchuk, M. Sychovy, O. Slipushko, V. Sumarokov, V. Fedosov, S. Yuriy. Today in financial science the question of a modern paradigm formation of systematic application of financial instruments system of business structures development, and also definition of their influence on business development remains little studied. Such a financial paradigm is a necessary condition for the formation and justification of the foundations of the integrated application of financial tools for the development of economic entities.

The purpose of the article (formulation of the problem). The main purpose of this study is exploring and systematization of knowledge about the impact of financial instruments on business development.

Presentation of the main research material. Based on the systematization of different approaches to the definition of the structure of the financial mechanism, taking into account the specifics of the functioning of agrarian enterprises, in the financial mechanism of sustainable development of agrarian enterprises. Seven main elements can be distinguished: the subsystem of financial policy, financial methods, financial levers, legal, normative and informational support, financial policy, as can be seen from the structure of the financial mechanism proposed by us. In this case, the financial mechanism operates effectively if all its constituent parts function. However, the state can provide them with financial policy [1].

Many factors influence the dynamics and effectiveness of financial instruments. They can be divided into two large groups: objective and subjective. Objective factors include: increasing the role of the state in supporting the development of priority sectors of the economy; state financial policy of Ukraine; priorities of economic policy; transition to market conditions of management; food security of the country; fulfillment of Ukraine's obligations in the international arena (WTO membership, EU requirements); the need for structural 
adjustment of the national economy; support of entrepreneurial activity in the agrarian sector; financing of priority sectors of the national economy. Subjective factors are: level of professional competence of executive and legislative staff; political positions of employees in executive and legislative structures of power; level of corruption (presence of ethical norms of behavior); availability of legal, normative and information base; availability and level of qualification of financial and crisis managers at agrarian enterprises. The combined effect of these groups of factors significantly influences the effectiveness of the use of financial instruments. Let us consider the most important components of it in more detail and give them a general scientific-theoretical description.

In economic practice, financial forecasting has long been used as one of the financial methods, which allows for predicting the development of economic processes for the future. The process of forecasting as scientific prediction, besides knowledge of economic laws, still requires scientific orientation and intuition. In this regard, financial forecasting is a far more sophisticated financial method than financial planning. If financial forecasting is a strategy for developing state finances in a certain perspective, then financial planning is tactical ways to achieve this perspective. From reliable financial forecasts, not only the quality of the implementation of current financial plans, but also the duration of their operational implementation will depend. According to O. Kyrylenko, financial planning is the activity of drawing up plans for the formation, distribution and use of financial resources at the level of individual economic entities, their associations, branch structures, territorial units and the country as a whole. The financial plans specify the main proportions of the distribution of the created value through satisfaction of their own production needs, directing part of the funds to pay taxes and mandatory fees, stimulating workers, investing temporarily free funds, etc. [2].

According to I. Petrovskaya, the main principles of financial planning should be considered: the scientific validity of the plans, which implies the balance of all financial, material and labor resources: the objective-purpose principle, which involves the definition of a specific purpose of financing, ensures the purposefulness of the use of financial resources [2]. In financial planning, an important role is assigned to the application of modern methods, namely: the method of coefficients; normative method; balance method. Financial planning actively influences the whole process of planning the national economy. Furthermore, if the state has achieved the conformity of the produced gross domestic product in cash and in kind, there is no discrepancy in the production and financial indicators, and the most balanced material, labor and financial resources, this indicates the high efficiency of using financial planning as a leading financial method.

Formation, adoption of the budget of the enterprise and further control over its use are called budgeting. The budgeting procedure is a norm for foreign companies and in recent years for Ukraine. In modern conditions, enterprises cannot work effectively if budgeting is not synchronized with the dynamics of economic development. Formation and approval of the budget - the most time-consuming part of the entire planning cycle, while more than $50 \%$ of enterprises do not take into account business planning at all when forming the budget. The most important tasks that are solved through budgeting are: planning of operations that ensure the achievement of the goals of the enterprise; coordination of different business and structural divisions; operational refreshment of the deviations of the actual results of the activities of enterprises; effective control over the expenditure of financial and material resources, providing planned discipline; encouraging managers of financial reporting centers to achieve the goals of their divisions; coordination of the interests of the workers of the enterprise [1;2]. According to I. Blank [3], budgeting as a financial technology consists of: technologies of budgeting; system of financial and economic indicators; organizations of budgeting, which foresaw the formation of the financial structure of the enterprise; use of information technologies, which allow developing various scenarios of the future finan- 
cial state of the enterprise, efficiently collecting, process and consolidating the actual data required for budget control.

The success of the introduction of a system of budgeting in agricultural enterprises depends on the dense elaboration of all regulations and procedures for the compilation and control of budget execution, as well as the level of qualification of the managers responsible for budgeting. In any case, at the time of implementation at the enterprise there should be a carefully weighed system of management accounting. The effectiveness of budgeting determines the efficiency of the enterprise as a whole. At the same time, the introduction and use of budgeting helps to identify and classify many of the problems of enterprises that have not been known before.

When executing financial plans, there is a need for operational management as an activity related to the need for intervention in distribution processes in order to eliminate disproportions, overcome bottlenecks, timely redistribution of funds, and ensure achievement of planned results. Both in the preparation of financial plans and in their implementation, as well as at the end of certain periods, financial control is carried out to verify the correctness of the cost allocation and the redistribution of the gross national product for the respective funds of funds and their use for the intended purpose. Financial control is a prerequisite for the smooth, efficient and gradual development of the economy as a whole country, as well as individual industries and enterprises. Savchuk V. states that financial control, as one of the functions of financial management, is a special activity of the respective structures in relation to verification of the formation and use of financial resources funds in the process of creation, distribution and consumption of gross domestic product in order to assess the validity and effectiveness of decision-making and the results of their performance at enterprises, in industries and in the state as a whole $[4 ; 5]$.

From the definition of the essence of financial control it follows that its object are the processes of formation and use of funds of financial resources. The subject of control is the carrier of control functions with respect to the control object. He, as a rule, is determined by the legislation of the state, normative legal acts of the subjects of financial activity. Types, forms and methods of financial control are presented in Figure 1.

Supposing that the most important principles of financial control are independence; publicity; preventive (preventive); effectiveness; regularity; objectivity; all-embracing character. Oparin V. proposed the classification of financial control, depending on the subjects of control, which distinguishes between such types of: state, departmental (intracorporate), internal economic, public and audit (independent). At the same time, state financial control involves state and municipal control [6]. The main feature of the national control is that it is non-departmental, conducted in relation to any subject, regardless of his departmental membership and subordination. This control is carried out by state bodies of legislative and executive power and special state bodies of control [7].

Departmental financial control extends to subordinate enterprises, organizations and institutions. The functions of departmental financial control include: verification of the legality of economic and financial transactions; control over the use of material and financial resources; verification of saving of funds and material values; the correctness of accounting, as well as the reliability of accounting reporting; conducting inspections at subordinate enterprises and organizations. The internal financial control is carried out by the economic services of enterprises, organizations, institutions (accounting, financial department, etc.), and in private enterprises by their owners. Public financial control is exercised by public organizations (parties, movements, trade union organizations).

Depending on the timing, the following forms of financial control are distinguished: preliminary, carried out before financial transactions; current, conducted in the process of financial transactions (transfer of taxes, fees, formation of funds, payments, etc.); the next, which is carried out after the end of certain periods, based on the results of the month, quarter, year. 


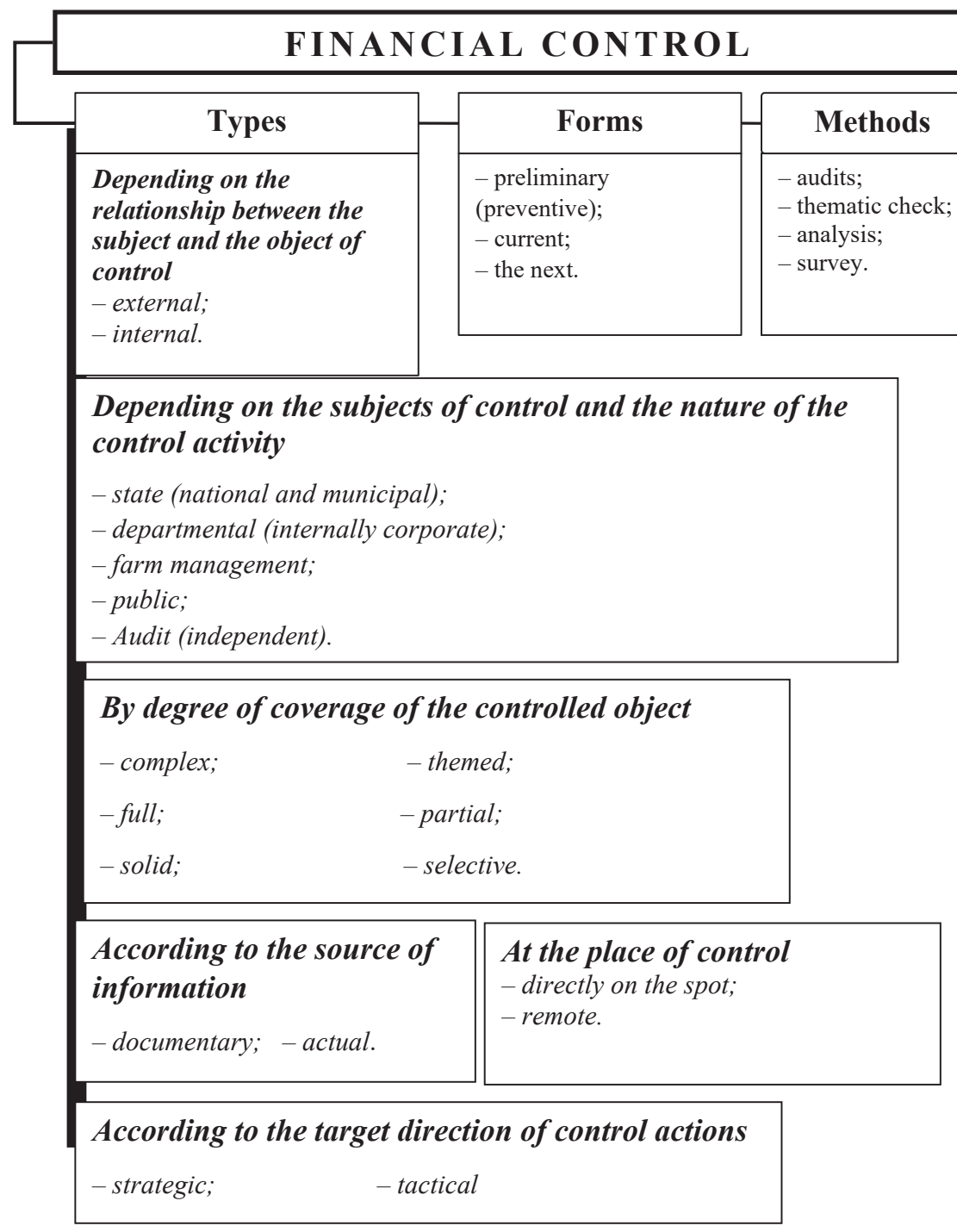

Figure 1. Types, forms and methods of financial control

Source: formed by the author on the basis of [1-8]

The prerequisite for ensuring the effectiveness of financial control is the optimality and systematic action of the controlling bodies. In other words, financial control can not be effective if it does not cover all spheres of the circulation of financial resources. Along with the consolidation of the legal framework of the activities of the supervisory bodies, strict professional standards are mandatory for those who are checked and those who check. In developed countries, professional requirements for control are fixed in standards developed by competent organizations and specialists within the framework of the current legislation. In Ukraine, control activities should also be carried out in accordance with the regulations a system of control procedures that should be standardized in order to ensure uniform understanding and use by both controlling bodies and controlled entities. 
Implementation of the system of distribution and redistributive relations takes place using the methods of financial provision of economic entities. Ospishcheva V. considers the main of them: budget financing as a provision of funds from the budget on irreversible terms; lending, that is, the provision of funds on the principles of turnaround, payment, timeliness and security; self-financing as a reimbursement of expenses of economic entities for the main activity and its development at the expense of its own sources (the principle of self-financing allows the attraction of credit resources); lease (leasing) involves the transfer of property for use for a certain fee and for a certain period; investing as a process of investing money in one or another object, with the expectation of increasing their value, as well as obtaining additional income [8].

Financial regulation of activity is primarily due to taxation, as the deduction of part of the income of enterprises and organizations, as well as of the population and the directing of these funds to the budgets and state target funds to meet state needs. In a market economy, the use of administrative methods of influence is too limited, and therefore the main emphasis in the regulation of the economy is on taxation [9].

The main instrument of socio-economic development as a managed process in a market economy is the economic and legal mechanism of state regulation, which includes both the system of privileges and subsidiary financial means of development, as well as a set of regulations and measures aimed at limiting certain unsatisfactory consequences of economic activity. In the theory of financial regulation of the economy there are two principal approaches:

1. Orthodox Keynesian. which has received widespread expansion in the first decades after the global economic crisis of 1929-1933. The basis of this method is the thesis of the self-sufficient effect of free enterprise, which heals the economy - "the invisible hand of the market", which is based on the idea of A. Smith about self-regulation of a market economy. This is a moderately-inflationary model of financial stabilization, or rather, a model of development with projected inflation. In accordance with this model, inflation becomes manageable, its creation potential is used for the priority purposes of economy. The main goals here are to support "effective" demand "and" full "employment by increasing government spending, wage limitation, information and cyclical tax policies. In accordance with the canons of economic theory - it is Keynesianism. The foundations of modern western "post-industrial" society in its classical form in the USA were created on the basis of the recipes of this model of development.

2. The theory of neo-liberalism or monetarism. The main focus of this theory is the use of various financial measures, in the main reduction of financial payments from the state budget for social measures (education, health care), liberalization of foreign trade, freedom of pricing, restriction of the governing economic role of the state. The basic principle of this concept is to intensify the policy of monetary and financial stabilization - a minimum of financial allocations from the budget in order to force the economy to work on the basis of self-reproduction mechanisms. This is monetarism in its purest form [6].

The ideas of monetarism are based (almost always) not on the development of production, but on the application to manage the cycle of economic reproduction of various financial measures. Among them, the priority is to reduce financial payments from the state budget, which leads, ultimately, to insufficient financing of national programs of health care, education, and demographic regulation. As a result, fertility is decreasing, the access of wide sections of the population to the services of health care institutions, education, culture and recreation is limited. The use of labor is reduced; there appears and becomes a proliferation of unemployment with a simultaneous reduction in production. At the historic stage of the statehood of Ukraine, the ideas of monetarism played a key role in the government's financial policy towards the development of the national economy.

The comparison of the main provisions of these two areas of financial regulation is presented in Table $1[2 ; 6]$. 
Table 1

The basic principles of the liberal concept and the concept of state regulation

\begin{tabular}{|c|c|c|}
\hline $\begin{array}{l}\text { Substantive } \\
\text { provisions }\end{array}$ & Liberal concept & Concept of state regulation \\
\hline $\begin{array}{l}\text { Roles of the } \\
\text { state in the } \\
\text { economy }\end{array}$ & $\begin{array}{l}\text { The minimum of interference, } \\
\text { function - creation and enforcement of } \\
\text { laws }\end{array}$ & $\begin{array}{l}\text { Active state regulation, including } \\
\text { prices; government procurement, } \\
\text { budget support for priority sectors, } \\
\text { widespread use of tax and other } \\
\text { benefits }\end{array}$ \\
\hline Monetary policy & $\begin{array}{l}\text { Fighting inflation and budget deficits, } \\
\text { hard money regulation }\end{array}$ & $\begin{array}{l}\text { Moderate inflation over a number } \\
\text { of years as a result of structural } \\
\text { deformations and a certain } \\
\text { monopolization of the economy, } \\
\text { reducing budget deficits is not an } \\
\text { end in itself. }\end{array}$ \\
\hline $\begin{array}{l}\text { Foreign- } \\
\text { economic policy }\end{array}$ & $\begin{array}{l}\text { Open economics: regulation of foreign } \\
\text { economic relations only with the help } \\
\text { of tariffs, consistent reduction of import } \\
\text { tariffs }\end{array}$ & $\begin{array}{l}\text { Protection of domestic commodity } \\
\text { producers: high tariffs on imports, } \\
\text { use of quotas and export-import } \\
\text { licenses }\end{array}$ \\
\hline $\begin{array}{l}\text { Ownership and } \\
\text { privatization }\end{array}$ & $\begin{array}{l}\text { Priority of private ownership, including } \\
\text { land ownership, high privatization rates, } \\
\text { protection of owners' rights }\end{array}$ & $\begin{array}{l}\text { Multilevel economics, high share of } \\
\text { the state sector, restriction of private } \\
\text { ownership of land (its sale and } \\
\text { purchase) }\end{array}$ \\
\hline $\begin{array}{l}\text { Structural and } \\
\text { investment } \\
\text { policy }\end{array}$ & $\begin{array}{l}\text { Structural shifts are a consequence } \\
\text { of the market, reliance on private } \\
\text { and foreign investment, public } \\
\text { investment - only in infrastructure and } \\
\text { social facilities }\end{array}$ & $\begin{array}{l}\text { Structural shifts are a consequence } \\
\text { of the market, reliance on private } \\
\text { and foreign investment, public } \\
\text { investment - only in infrastructure } \\
\text { and social facilities }\end{array}$ \\
\hline Social policy & $\begin{array}{l}\text { Addressing social support, job creation } \\
\text { and earning conditions is recognized as } \\
\text { more important than individual social } \\
\text { guarantees. Stimulates the development } \\
\text { of private pension funds and insurance } \\
\text { companies }\end{array}$ & $\begin{array}{l}\text { State guarantees of a certain standard } \\
\text { of living and employment, relying } \\
\text { on state pension provision and state } \\
\text { social insurance }\end{array}$ \\
\hline
\end{tabular}

In general, financial regulation is carried out through: a system of norms; limits; financial reserves [6]. Paying attention to the essence and characteristics of financial methods. Thus, M. Carlin defines the financial method as a means of influencing financial relations in the economic process. Financial methods operate in two directions: the management of the movement of financial resources and market-based commercial relations, associated with changes in costs and results, material incentives and responsibility for the efficient use of funds. The effect of financial methods is manifested in the formation and application of monetary funds [10].

An analytical approach to the definition and evaluation of the most important financial methods of the financial mechanism of the organization of economy allows us to distinguish the following methods: planning (forecasting); investment; lending; financing; pricing; taxation; economic calculation; fund formation; insurance; discounting. According to A. Podderyogin, each of these financial methods has a certain set of financial levers. For example, leverage, such as leasing, leasing, factoring, transfer, franchising, etc., is used in the lending method; methods of pricing are - prices, exchange rates, exchange rates, wages, interest, etc. [11]. Specific forms of implementation of the processes of distribution and redistribution of the created value are financial leverage, which are the means of action of financial methods. 
These include: taxes, compulsory fees, depreciation rates, norms for spending on budget institutions, rent, interest on loans, subsidies, subsidies, subventions, incentive funds, fines, penalties, bonuses, etc. The feature of financial leverage is that they are based on the consideration of the economic interests of the state, enterprises, organizations, people $[8 ; 12 ; 13]$.

Among all financial levers, a special place is occupied by taxes and fees, through which the state mobilizes funds to perform its functions, as well as affects and encourages entrepreneurial activity, promotes investment activity, determines the proportions of accumulation and consumption, provides rationality [14]. The use of limited natural resources, etc. The taxation system in Ukraine is underway in the process of reforming, reducing the tax burden on producers, granting privileges to investors and exporters of finished products, ensuring simplicity in tax collection, avoiding double taxation, and increasing liability for tax payments [16].

One of the directions of the state's influence on the pace of social reproduction is the establishment of rates of depreciation, the determination of depreciation methods, and the use of accelerated depreciation to promote the development of scientific and technological progress. In this case, the scientific substantiation of the sizes of the rates of depreciation becomes significant because both their significant increase and the decrease has negative consequences. Among all financial levers, a special place is occupied by taxes and fees with which the state mobilizes funds to perform its functions, as well as affects entrepreneurial activity, promotes investment activity, determines the proportions of accumulation and consumption, ensures the rational use of limited natural resources, etc. [12; 14].

Limits are a certain constraint on costs in the interests of the state, entrepreneur or citizen. Reserves should neutralize the impact of unpredictable factors that may arise in the future. According to K. Pavlyuk, the main methods of forming financial reserves are: budget (creation of a reserve fund in each budget); sectoral (creation of reserves at the level of ministries, branches, departments); self-supporting (formation of financial reserves of enterprises, organizations, institutions); insurance (creation of funds of insurance organizations) [17].

Considering special financial privileges, S. Yuriy and others emphasized that they promote the creation of favorable conditions for certain economic entities and are used mainly in the form of full or partial exemption from taxes, the application of differentiated rates of taxation, the exclusion of certain amounts from taxable income, the right to conduct accelerated depreciation [14]. At the same time, the market mechanism provides for the creation of equal conditions for activities for all business entities, and therefore the list of benefits in taxation should not be significant.

Financial leverage occupies an important place in financial sanctions as special forms of organization of financial relations, designed to increase the liability of economic entities in fulfilling their obligations (contractual terms, taxes and fees, etc.). At the same time, in the market conditions, the role of financial sanctions increases significantly. The most widespread among them is a fine and a penalty. Fine is a measure of material influence on the perpetrators in violation of legislation, agreements or operating rules. Penalty is applied in case of untimely execution of monetary obligations and accrued for each day of delay.

Conclusions. Thus, the effectiveness of financial instruments depends on the effectiveness of using its individual elements. Only the complex application of all financial instruments can ensure the qualitative development of business entities. Among all financial levers, a special place is occupied by taxes and fees, through which the state mobilizes funds to perform its functions, as well as affects and encourages entrepreneurial activity, promotes investment activity etc. In a market economy, the use of administrative methods of influence is too limited, and therefore the main emphasis in the regulation of the economy is on taxation and financial stimulation of business structures development. Issues of ensuring the financial stability of business entities, strengthening their financial security, as well as identifying factors that affect the state and development of enterprise financing may be topics for further research. 


\section{References:}

1. Tanklevska N. S., Yarmolenko V. V., Synenko O. O. (2020) Modernizatsiia finansovoho mekhanizmu u sferi rehionalnoho ahrobiznesu. Ahrosvit, no. 15, pp. 11-17. Available at: http://www.agrosvit.info/pdf/15 2020/3.pdf (accessed 01 November 2021).

2. Petrovska I.O. [ta in.] (2002) Finansy (z elementamy statystyky finansiv). [Navchal'nyy posibnyk]. Kyiv: TSUL, $300 \mathrm{p}$.

3. Blank Y.A. (2004) Fynansovyy menedzhment: Uchebnyy kurs. Kyiv: Finansy i statystyka, 656 p.

4. Savchuk V.P. (2009) Stratehyya + Fynansy: uroky prynyatyya byznes-reshenyy dlya rukovodyteley. Kyiv: Companion Group, 352 p.

5. Tanklevska N.S., Kyrylov Y.Y., Zaitseva O.I. (2017) Management of conscious adaptive organizations in the context of socioeconomic changes and financial turbulence. Scientific bulletin of Polissia, no. 4(12), pp. 36-39.

6. Oparin V.M. (1999) Finansy (zahal'na teoriya): [Navch. posib.]. Kyiv: KNEU, 164 p.

7. Hudz' O.Ye., Strel'nikova S.Yu. (2019) Orhanizatsiyno-informatsiyne zabezpechennya upravlinnya rozvytkom pidpryyemstva $\mathrm{v}$ umovakh stanovlennya tsyfrovoyi ekonomiky. Ekonomika. Menedzhment. Biznes, no. 4(30), pp. 4-13. Available at: http://journals.dut.edu.ua/index.php/emb/ article/view/2332 (accessed 03 November 2021).

8. Ospishcheva V.I. [ta in.] (2008) Finansy: kurs dlya finansystiv: Navch. posibnyk / za red. Kyiv: Znannya, $567 \mathrm{p}$.

9. Tanklevska N., Povod T., Ostapenko A., Borovik L. (2021) Crowdfunding Development Trends: Foreign Experience and Ukrainian Realities in the Digital Economy. Conference Paper. Lecture Notes in Networks and Systems. 194 LNNS, pp. 897-908. Available at: https://link.springer.com/ chapter/10.1007\%2F978-3-030-69221-6_69 (accessed 03 November 2021).

10. Karlin M.I. (2004) Finansy zarubizhnykh krayin: [Navchal'nyy posibnyk]. Kyiv: Kondor, 384 p.

11. Poddyer'ohin A.M. [ta in.] (1998) Finansy pidpryyemstv: [pidruchnyk]. Kyiv: KNEU, 353 p.

12. Tanklevska N., Miroshnichenko V. (2019) Theoretical basis of managing of enterprises financial potential on the basis of anti-crisis management. Agricultural and Recourse Economics: International Scientific E-Journal, no. 2, vol. 5, pp. 51-61. Available at: https://are-journal.com/index. php/are/article/view/236/197 (accessed 05 November 2021).

13. Khudoliy L.M., Slyesar V.M. (2019) Rozvytok kredytnykh spilok v Ukrayini. Oblik i finansy, no. 85, pp. 113-121. Available at: https://cutt.ly/kTJxiFH (accessed 04 November 2021).

14. Yuriy S.I., Fedosov V.M. [ta in.] (2008) Finansy: [Pidruchnyk]. Kyiv: Znannya, 611 p.

15. Kyrylov Y.Y., Tanklevska N.S., Zhosan G.V. (2018) Viral management as a subset of creative management in conditions of financial instability. Scientific bulletin of Polissia, no. 2(14), pp. 160-164. Available at: http://ir.stu.cn.ua/handle/123456789/16968 (accessed 01 November 2021).

16. Bechko P.K., Barabash L.V., Lysa N.V. (2019) Podatkovi pil'hy yak instrument realizatsiyi kontseptsiyi spravedlyvosti v opodatkuvanni. Modern Economics, vol. 13, pp. 18-24. Available at: https://cutt.ly/kTJvyAV (accessed 04 November 2021).

17. Pavlyuk K.V. (2006) Byudzhet i byudzhetnyy protses v umovakh tranzytyvnoyi ekonomiky Ukrayiny: [Monohrafiya]. Kyiv: NDFI, 584 p. 